\title{
Dampak Kuliah Kerja Nyata \\ Dalam Pengembangan Keagamaan Bagi Remaja
}

\author{
Ceni Eka Putri Wulandari, Sugiatno, Siswanto \\ Institut Agama Islam Negeri (IAIN) Curup, Indonesia \\ cheniekaputriwulandari@gmail.com, sugiatno@gmail.com, \\ sis66505@gmail.com
}

\begin{abstract}
The field work study can bring about new changes in society, and one of which is in the religious field. Thus, there will be an impact of field work study. As in the field work study held in Cawang Lama Village, students as the agents of change can make a real contribution to society through this program. Accordingly, this research aims to find out the impact of field work study on adolescents' religious development in Cawang Lama Village. Religious development is supported by several factors, one of which is the field work study which has a very influential impact on society. The type of this research is field research with a qualitative descriptive approach. The object is Cawang Lama Village, and the subjects are adolescents. From this research, it is known that the field work study has a positive impact on adolescents' religious development through the programs that have been implemented by students.
\end{abstract}

Keywords: Field Work Study, Religion, Society

\begin{abstract}
Abstrak
Kuliah Kerja Nyata (KKN) dapat mewujudkan perubahan baru di masyarakat salah satunya di bidang keagamaan, sehingga akan ada dampak yang ditimbulkan dari diadakannya Kuliah Kerja Nyata $(\mathrm{KKN})$ tersebut. Seperti halnya Kuliah Kerja Nyata (KKN) yang dilakukan di Desa Cawang Lama, mahasiswa sebagai agent of change dapat memberikan kontribusi nyata kepada masyarakat melalui program KKN ini. Dalam hal ini bertujuan untuk mengetahui dampak dari Kuliah Kerja Nyata (KKN) terhadap pengembangan kegaaman bagi remaja di Desa Cawang Lama. Pengembangan keagamaan didukung oleh beberapa faktor, salah satunya adalah Kuliah Kerja Nyata $(\mathrm{KKN})$ yang dampaknya sangat berpengaruh di masyarakat. Jenis Penelitian ini merupakan penelitian Lapangan (field research) dengan pendekatan deskriptif kualitatif yang Objeknya adalah Desa Cawang Lama serta Subjeknya adalah remaja. Dalam Penelitian ini diketahui bahwa dampak KKN
\end{abstract}

FOKUS : Jurnal Kajian Keislaman dan Kemasyarakatan Vol. 5, No. 2, 2020

LPPM Institut Agama Islam Negeri (IAIN) Curup - Bengkulu

p-ISSN 2548-334X, e-ISSN 2548-3358

DOI: $10.29240 /$ jf.v5i2.1830 | p. 221-236 
dalam pengembangan keagamaan bagi remaja menghasilkan dampak yang positif melalui program-program yang telah dilaksanakan oleh mahasiswa.

Kata Kunci: Kuliah Kerja Nyata (KKN), Pengembangan Keagamaan, Remaja

\section{Pendahuluan}

Direktur jenderal pendidikan tinggi memberikan istilah kuliah kerja nyata $(\mathrm{KKN})$ sebagai bentuk pengabdian mahasiswa kepada masyarakat, yang sampai sekarang sebagian besar Perguruan Tinggi menjadikan kuliah kerja nyata $(\mathrm{KKN})$ sebagai bagian dari kegiatan yang wajib ditempuh oleh para mahasiswa dalam proses perkuliahan. Namun dalam konsep dan implementasinya masih belum fokus pada model kuliah kerja nyata yang tepat dengan kebutuhan masyarakat yang bervariatif dari segi agama, ekonomi, budaya, dan sosial. $^{1}$

Kuliah kerja nyata (KKN) juga merupakan mata kuliah wajib yang harus ditempuh oleh mahasiswa dan bersifat intrakurikuler yang juga memberikan pendidikan kepada mahasiswa. Kegiatan kuliah kerja nyata itu sendiri pelaksanaannya langsung terjun ke lapangan dan melibatkan masyarakat sehingga kuliah kerja nyata realisasinya harus memberikan manfaat bagi masyarakat dan mahasiswa itu sendiri. Oleh karena itu, kuliah kerja nyata tidak hanya memberikan pendidikan saja, tetapi juga sebagai pengembangan diri bagi mahasiswa, berinteraksi dengan masyarakat, berpartisipasi dalam kegiatan masyarakat, serta membantu pemerintah dalam pengembangan dan pembangunan yang bersifat membangun bagi masyarakat itu sendiri. ${ }^{2}$

Kuliah kerja nyata adalah bentuk kegiatan pengabdian kepada masyarakat oleh mahasiswa dengan pendekatan lintas keilmuan dan sektoral pada waktu dan daerah tertentu. ${ }^{3}$ Pelaksanaan kegiatan kuliah kerja nyata

\footnotetext{
${ }^{1}$ Hidayat, Nur.”Model Kuliah Kerja Nyata (KKN) Integratif Interkonektif Berbasis Pada Masyarakat Yang Produktif Inovatif Dan Kreatif." Panangkaran: Jurnal Penelitian Agama dan Masyarakat 2.2 (2019): 219-238.

2 Nurjanah, Nurjanah, and Ori Permata Lani.”Opini Mahasiswa terhadap Pelaksanaan Kuliah Kerja Nyata (Kukerta) di Universitas Riau." Jurnal Online Mahasiswa Fakultas Ilmu Sosial dan Ilmu Politik Universitas Riau1.2 (2014).

3 Nurjanati, Dwi. "Pemasukan Materi Literasi Keuangan Dalam Kurikulum Program Kuliah Kerja Nyata (Kkn) Sebagai Media Edukasi Literasi Keuangan Pelaku UMKM." Prosiding Seminar Pendidikan Ekonomi dan Bisnis. Vol. 3. No. 1. 2017.
} 
biasanya berlangsung antara satu sampai dua bulan dan bertempat di daerah setingkat desa. Direktorat Jenderal Pendidikan Tinggi di Indonesia telah mewajibkan setiap perguruan tinggi untuk melaksanakan kuliah kerja nyata sebagai kegiatan intrakurikuler yang memadukan tri dharma perguruan tinggi yaitu: pendidikan, penelitian, dan pengabdian kepada masyarakat. Skill maupun kemampuan mahasiwa akan sangat dibutuhkan dalam menunjang proses kuliah kerja nyata, sehingga tujuan dari kuliah kerja nyata sendiri akan tercapai. ${ }^{4}$ Kemudian, ada banyak persoalan di tengah masyarakat yang sedemikian rumit sehingga tidak cukup hanya menggunakan logika keagamaan untuk menyelesaikannya, tetapi diperlukannya disiplin keilmuan lainnya agar dapat memecahkannya. ${ }^{5}$

Melalui kuliah kerja nyata, mahasiswa dapat belajar mengenali kelemahan dan pengembangan kemampuannya untuk mengatasi berbagai persoalan yang ada di tengah masyarakat. Memahami realitas struktural yang menindas dan sadar akan posisinya dalam realitas tersebut. Jika kesadaran mahasiswa tersebut tumbuh, maka akan tumbuh pula kehendak yang kuat untuk melakukan perubahan dalam rangka memperbaiki kualitas kehidupan masyarakat. Pada kenyataan di lapangan, mahasiswa dalam menjalankan kuliah kerja nyata hanya untuk menyelesaikan beban Satuan Kredit Semester (SKS) saja, hal ini terbukti dari beberapa kelompok mahasiswa yang mengikuti kuliah kerja nyata di beberapa daerah tidak memiliki hasil yang spesifik selama masa pengabdian. Selain itu, mahasiswapun kurang memahami tujuan kuliah kerja nyata itu sendiri. Sehingga dalam pelaksanaannya masih terlihat kurang maksimal. ${ }^{6}$

Masyarakat akademik khususnya para mahasiswa mempunyai kesempatan langsung dalam pembangunan pemberdayaan masyarakat karena hadirnya perguruan tinggi itu memerlukan masyarakat dam masyarakat memerlukan perguruan tinggi. Setiap program kerja yang dilaksanakan dalam kegiatan kuliah kerja nyata memberikan manfaat untuk memberikan solusi atas permasalahan-permasalahan. Program-program tersebut diantaranya, kurangnya dalam mempelajari keagamaan seperti membaca dan menulis Al-

${ }^{4}$ Ardyansyah, Johan. "Pemilihan Tempat KKN (Kuliah Kerja Nyata).

${ }^{5}$ Salehudin, Ahmad.” Pelaksanaan KKN Berparadigma Integrasi-Interkoneksi dalam Menopang Transformasi Masyarakat (Sebuah Rintisan Pendekatan Participatory Action Research).” Aplikasia: Jurnal Aplikasi Ilmu-ilmu Agama16.2 (2017): 63-72.

${ }^{6}$ Ibid., hlm.56 
Quran, masyarakat yang kurang perduli dengan pendidikan anak-anaknya sehingga masih ada anak-anak yang seharusnya sekolah tetapi tida sekolah. ${ }^{7}$

Kuliah kerja nyata atau pengabdian masyarakat memiliki manfaat yang besar bagi mahasiswa untuk meningkatkan kualitas diri. Melalui pengalaman yang didapatkan dari masyarakat dan menjadikan hal tersebut suatu perubahan dimasa yang akan datang. Kuliah kerja nyata merupakan program yang mengintegrasikan secara menyeluruh ilmu yang dimiliki ke dalam wujud pengabdian kepada masyarakat dengan cara memberikan pengalaman belajar kepada mahasiswa dan bekerja dalam berbagai kegaiatn masyarakat sebagai wahana penerapan dan pengembangan ilmu yang telah didapatkan dan diaplikasikan kepada masyarakat. ${ }^{8}$

Penyelenggara kuliah kerja nyata, secara umum memiliki dua pendekatan utama, yaitu kuliah kerja nyata berpendakatan tematik dan kuliah kerja nyata pendakatan mandiri. Dalam kuliah kerja nyata pendakatan tematik, universitas menetapkan tema yang mencerminkan bidang, tujuan dan sasaran seluruh program kerja yang dikembangkan dan dilaksanakan oleh kelompok mahasiswa kuliah kerja nyata. Dalam kuliah kerja nyata pendekatan mandiri, universitas memberikan kebebasan kepada kelompok mahasiswa kulia kerja nyata untuk mengembangkan dan melaksanakan program kerja berdasarkan hasil asesmen masalah dan atau kebutuhan masyarakat sasaran. ${ }^{9}$

Dalam observasi, ${ }^{10}$ penulis melihat fenomena ini, pokok masalah peneliti adalah dampak kuliah kerja nyata dalam pembangunan dan pengembangan keagamaan bagi remaja Desa Cawang Lama. Dalam penelitian ini, penulis melibatkan remaja sebagai sebagai objek penelitian.

Pada dasarnya penelitian ini dilakukan dengan merujuk pada penelitian terdahulu seperti pada penelitian tentang opini mahasiswa terhadap pelaksanaan kuliah kerja nyata yang ditulis oleh Oktri Permata Lani yang

${ }^{7}$ Amir, Fachrur Razi, and Syamsuddin Ali Nasution. "Pemberdayaan Masyarakat Melalui Kegiatan Pendidikan, Agama, Sosial, Ekonomi, Dan Kesehatan." Qardhul Hasan: Media Pengabdian Kepada Masyarakat 3.1 (2018).

8 Widyasari, Widyasari, And Novi Maryani. Meningkatkan Peran Masyarakat Melalui Program Pendidikan Berbasis Tauhid Dalam Pembangunan Desa Yang Mandiri, Kreatif Dan Berbudaya. Qardhul Hasan: Media Pengabdian Kepada Masyarakat 3.1 (2018).

${ }^{9}$ Pemungkas, Alim Harun. Pengembangan Program Kuliah Kerja Nyata untuk Pemberdayaan Masyarakat Desa. (2016).

${ }^{10}$ Observasi, 15 Mei 2020 
dalamnya dijelaskan bahwa kuliah kerja nyata pelaksanaannya di lapangan dan memerlukan keterlibatan masyarakat, sehingga realisasinya memberikan manfaat bagi masyarakat serta membantu pemerintah dalam melancarkan kegiatan yang sifatnya membangun. ${ }^{11}$ Selanjutnya penelitian tentang pemberdayaan masyarakat melalui kegiatan pendidikan, agama, sosial, ekonomi, dan kesehatan yang ditulis oleh Amir, dalam jurnal tersebut menjelaskan bahwa kuliah kerja nyata merupakan program wajib yang diikuti oleh seluruh mahasiswa sebagai bentuk pengabdian kepada masyarakat untuk ikut dapat berpartisipasi dalam membangun desa pada segala bidang baik itu pendidikan, keagamaan, usaha ekonomi masyarakat, lingkungan, social, kesehatan dan infrastruktur ${ }^{12}$ Serta penelitian tentang model kuliah kerja nyata integratif interkonektif berbasis pada pengembangan masyarakat yang produktif inovatif dan kreatif yang ditulis oleh Nur Hidayat dan Sri Purnama, dalam jurnal ini menjelaskan bahwa melalui kuliah kerja nyata mahasiswa dapat mengenali kelemahan dan pengembangan kemampuannya untuk mengatasi berbagai persoalan yang ada di dalam masyarakat, memahami realitas struktural yang menindas dan sadar akan posisinya dalam realitas tersebut. Jika kesadaran tumbuh, maka akan tumbuh pula kehendak yang kuat untuk melakukan perubahan dalam rangka memperbaiki kualitas kehidupan masyarakat. ${ }^{13}$

Dalam penelitian terdahulu yang peneliti temukan seperti yang telah dijelaskan di atas, menunjukkan bahwa penelitian tersebut hanya menjelaskan tentang kuliah kerja nyata saja. Sedangkan terkait pembahasan mengenai dampak kuliah kerja nyata bagi pengembangan keagamaan belum ada bahasannya dalam penelitian yang sudah dilakukan tersebut. Jadi, dasar permasalahan yang tengah terjadi di Desa Cawang Lama yang di khususkan pada dampak kuliah kerja nyata dalam pengembangan keagamaan bagi remaja sehingga dapat diketahui penelitian ini lebih mendasar pada pengembangan

11 Nurjanah, Nurjanah, and Oktri Permata Lani."Opini Mahasiswa terhadap Pelaksanaan Kuliah Kerja Nyata (Kukerta) di Universitas Riau." Jurnal Online Mahasiswa Fakultas Ilmu Sosial dan Ilmu Politik Universitas Riau1.2 (2014).

12 Amir, Fachrur Razi, and Syamsuddin Ali Nasution. "Pemberdayaan Masyarakat Melalui Kegiatan Pendidikan, Agama, Sosial, Ekonomi, Dan Kesehatan." Qardhul Hasan: Media Pengabdian Kepada Masyarakat 3.1 (2018): 61-73.

${ }^{13}$ Hidayat, Nur.”Model Kuliah Kerja Nyata (KKN) Integratif Interkonektif Berbasis Pada Masyarakat Yang Produktif Inovatif Dan Kreatif." Panangkaran: Jurnal Penelitian Agama dan Masyarakat 2.2 (2019): 219-238. 
keagamaan yang sangat berbeda dengan penelitian sebelumnya.

Adapun tujuan dalam penelitian ini diharapkan dapat mengetahui dampak dari kuliah kerja nyata terhadap pengembangan keagamaan bagi remaja Desa Cawang Lama. Kemudian diharapkan agar remaja mempunyai pengetahuan mengenai aspek-aspek keagamaan sehingga pengembangan keagamaan di Desa Cawang Lama dapat berkembang lebih baik dan kuliah kerja nyata yang dilaksanakan oleh mahasiswa dapat menghasilkan dampak yang baik bagi masyarakat.

Jenis peneitian ini menggunakan metode kualitatif, dengan tujuan untuk mendeskripsikan fenomena yang terjadi (deskriptif kualitatif). Penelitian kualitatif dimaksud sebagai jenis penelitian yang temuantemuannya tidak diperoleh melalui prosedur statistik atau bentuk hitungan lainnya. Sedangkan deskriptif merupakan penelitian yang bertujuan untuk memberikan sebuah gambaran tentang suatu kelompok orang tertentu atau gambaran tentang suatu yang mempunyai gejala atau lebih. ${ }^{14}$ Jenis penelitian ini adalah penelitian Lapangan, yaitu penelitian yang pengumpulan datanya dilakukan di lapangan. Dalam hal ini dilakukan di Desa Cawang Lama. Tempat penelitian ini dilakukan di lokasi yang menjadi sumber penelitian yaitu di Desa Cawang Lama. Kemudian waktu penelitian dimulai pada tanggal 10 bulan Juni 2020.

Subjek penelitian ialah sumber utama data penelitian, yakni yang memiliki data mengenai variabel-variabel yang akan diteliti. Jadi subjek penelitian adalah pihak-pihak yang dijadikan sampel dalam sebuah penelitian. ${ }^{15}$ Karena penelitian ini untuk mendapatkan gambaran tentang dampak kuliah kerja nyata $(\mathrm{KKN})$ dalam pengembangan kegamaan bagi remaja di Desa Cawang Lama maka subyeknya adalah remaja yang ada di Desa Cawang Lama. Oleh sebab itu informasi yang akan diperoleh diharapkan merupakan informasi yang benar-benar dapat mengetahui tanggapan dari sampel yang peneliti ambil di Desa Cawang Lama yakni beberapa masyarakat terutama remaja. Dalam penelitian ini yang dimaksud dengan sumber data

\footnotetext{
${ }^{14}$ Lexy J.Moleong, Metodologi Penelitian Kualitatif Edisi Revisi, (Bandung: Remaja Rosdakarya, 2006), hlm. 4

${ }^{15}$ Saifuddin Azwar, Metode Penelitian, (Yogyakarta: Pustaka Pelajar, 2012), hlm. 34
} 
penelitian adalah subjek dari mana data yang dapat diperoleh. ${ }^{16}$ Adapun sumber data yang penulis gunakan dalam penelitian ini adalah menggunakan dua sumber data yaitu sumber data primer data yang berupa teks seperti hasil dari wawancara yang diperoleh melalui wawancara dengan seorang informan yang sedang disajikan sampel serta dalam penelitiannya data tersebut bisa direkam atau dicatat oleh seorang peneliti. Adapun sumber data primer dalam penelitian ini adalah masyarakat remaja Desa Cawang Lama. Data sekunder dalam penelitian ini yang terhimpun dari instansi terkait berupa dokumen Desa Cawang Lama.

Teknik pengumpulan data dalam penelitian ini meliputi observasi, wawancara, dan dokumentasi. ${ }^{17}$ Dalam penelitian ini Observasi dalam pengamatan dan pencatatan secara langsung tentang gambaran kuliah kerja nyata $(\mathrm{KKN})$ dan dampaknya dalam pengembangan kegamaan di Desa Cawang Lama. Kemudian Wawancara merupakan suatu cara memperoleh keterangan data untuk tujuan penelitian. Selanjutnya Dokumentasi yang merupakan catatan peristiwa yang telah berlalu, dokumen bisa berbentuk tulisan, gambar, atau karya-karya monumental dari seseorang. ${ }^{18}$ Hasil penelitian dari wawancara, akan lebih dapat dipercaya apabila didukung oleh sebuah dokumen.

\section{Hasil Dan Pembahasan}

\section{Dampak Kuliah Kerja Nyata Bagi Remaja}

Kuliah kerja nyata merupakan bentuk kegiatan pengabdian kepada masyarakat yang dilakukan pada waktu dan daerah tertentu. Pelaksanaan kuliah kerja nyata biasanya berlangsung antara satu bulan sampai dengan dua bulan. Kuliah kerja nyata termasuk salah satu tri dharma perguruan tinggi dalam bentuk pengabdian kepada masyarakat sehingga kuliah kerja nyata merupakan suatu keharusan yang harus dilakukan dan mata kuliah wajib yang ditempuh oleh mahasiswa yang bersifat intrakurikuler. ${ }^{19}$

Pada sekarang ini salah satu tujuan KKN adalah mengembangkan

${ }^{16}$ Suharsimi Arikunto, Prosedur Penelitian Suatu Pendekatan Praktek, (Jakarta: Rineka Cipta, 2014), hlm. 172

${ }^{17}$ Sugiyono, Metode Penelitian Pendidikan, (Bandung: Alfabeta, 2018), hal. 310 hlm. 90

${ }^{18}$ Sudaryono, Metode Penelitian Pendidikan, (Jakarta: Prenamedia Group, 2016),

${ }^{19}$ Masyarakat, Hakikat Pengabdian Pada. "Hakikat Pengabdian Pada Masyarakat Dan Arah Kebijakan Kuliah Kerja Nyata (Kkn) Di Stkip Pgri Jombang." 
pengetahuan agama dan membantu pemerintah dalam mempercepat proses pembangunan dibidang keagamaan dan pendidikan. Sasaran yang ingin dicapai yaitu meningkatkan kualitas keagamaan, pendidikan ditengah masyarakat dengan cara pelatihan, penyuluhan dan lain sebagainya. Dalam penelitian ini sasaran utama dalam pengembangan dan pembangunan keagamaan adalah remaja, sebab masa remaja merupakan masa yang progresif. ${ }^{20}$

Tidak dapat dipungkiri bahwa kuliah kerja nyata merupakan hal yang sangat penting dalam pembangunan dan pengembangan keagamaan. Melalui kuliah kerja nyata, mahasiswa dapat mewujudkan remaja yang islami. Namun dalam hal ini bukan hal yang mudah bagi para mahasiswa dalam membangun dan mengembangkan sifat keagamaan bagi remaja. Hal ini disebabkan berbagai faktor, salah satunya dengan perkembangan zaman yang sangat memberikan pengaruh besar pada remaja. Perkembangan zaman saat ini mampu mengubah pola pikir remaja, namun kembali lagi dengan keadaan lingkungan. Dalam hal ini lingkungan sekitar dan masyarakat tentu sangat berpengaruh pada karakter remaja, dan juga terdapat peran mahasiswa di dalamnya. ${ }^{21}$

Demikian juga kuliah kerja nyata yang dilakukan oleh mahasiswa perguruan tinggi IAIN Curup yang turut serta dalam membangun dan mengembangkan keagamaan pada remaja. Melalui program kerja yang dirancang, mahasiswa mampu membantu perintah dalam pembangunan dan pengembangan keagamaan pada remaja. Dengan kata lain hal ini merupakan kesempatan bagi mahasiswa dalam meningkatkan potensi dan menerapkan ilmu yang telah dipelajari.

Pada zaman modern ini banyak tantangan dan permasalahan yang dihadapi oleh masyarkat Indonesia. Kehidupan yang glamour dan individualis merupakan gaya hidup pada era modern ini bahkan siklus perubahan yang terjadi pun sangat cepat, kemajuan bidang IPTEK juga demikian. Teknologi dan internet misalnya, semakin berakar dalam kehidupan manusia tanpa mengenal bangsa dan negara. Kemajuan IPTEK di satu sisi harus diakui telah

\footnotetext{
${ }^{20}$ Observasi, 10 Mei 2020

${ }^{21}$ Wawancara dengan Satrio, Remaja Desa Cawang Lama, Tanggal 12 Juni 2020
} pukul 14:00 WIB 
mempengaruhi dan memperbaiki taraf serta mutu kehidupan. ${ }^{22}$

Membangun dan mengembangkan keagamaan pada remaja bisa dikatakan merupakan tujuan utama, hal ini dikarenakan dengan adanya perkembangan zaman yang berkembang sangat cepat, kemudian diikuti dengan teknologi informasi dan komunikasi. Hal ini merupakan ancaman nyata dan sekaligus sebagai tantangan bagi mahasiswa dan bangsa Indonesia dalam merebut masa depan bangsa terutama masa depan yang religius.

Upaya mahasiswa dalam menjawab tantangan tersebut merupakan upaya untuk melahirkan sumber daya manusia yang berkualitas yang ditempuh melalui pendidikan, baik pendidikan formal, informal, maupun nonformal. Maka dalam hal ini, program kuliah kerja nyata merupakan kesempatan dalam mewujudkan hal tersebut, sehingga diharapkan mahasiswa mampu memiliki berbagai macam metode dalam mewujudkan dan mengembangkan keagamaan pada remaja. Demikian pula dalam peningkatan iman dan taqwa sangat diperlukan, karena nilai-nilai agama di masa yang serba canggih ini sudah merosot dan mulai memudar. Maka untuk itu, tugas mahasiswa sebagai bentuk pengabdiannya kepada masyarakat salah satunya adalah dengan cara membangun dan mengembangkan kembali remaja terutama dalam bidang keagamaan. ${ }^{23}$

Kegiatan pengembangan keagamaan pada remaja di desa Cawang Lama yang dilakukan oleh mahasiswa kuliah kerja nyata adalah dengan cara menghidupkan kembali remaja islam masjid (risma) desa Cawang Lama. Peran remaja masjid sangatlah penting terutama dalam membentuk dan membangun generasi islam serta pembentukan karate yang religious. Melalui peran remaja masjid, masjid mampu menjadi wadah pembentukan karakter serta pendidikan karakter bagi masyarakat sekitar khususnya remaja-remaja yang dalam dunia nyata pergaulannya sekarang ini sangat rawan. ${ }^{24}$

Dalam rangka mengembalikan nilai religius pada remaja dan anakanak, maka mahasiswa kuliah kerja nyata berupaya melakukan berbagai macam kegiatan secara rutin. Harapannya adalah melalui kegiatan tersebut akan timbul kedasaran dan mampu meningkatkan nilai religious dalam diri

\footnotetext{
${ }^{22}$ Observasi, 10 Mei 2020

${ }^{23}$ Wawancara dengan Aris, Warga Desa Cawang Lama, Tanggal 11 Juni 2020 pukul 11:10 WIB

${ }^{24}$ Observasi, 10 Mei 2020
} 
masing-masing remaja. adanya kuliah kerja nyata memberikan dampak yang positif, hal ini dikarenakan adanya sifat membangun. Dalam hal ini adalah pada bidang keagamaan pada remaja. Bagi perguruan tinggi keagamaan, ini merupakan kesempatan bagi mahasiswa untuk menjadikan remaja yang berjiwa religious, agamamis, dan memberikan sedikit banyakya tentang pengetahuan keagamaan melalui program kerja peserta kuliah kerja nyata. Program kuliah kerja nyata diharapkan tidak bersifat sementara atau hanya berlangsung pada masa kuliah kerja nyata saja, tetapi bersifat terus menerus agar dapat memberikan dampak yang positif bagi remaja maupun yang lainnya. Mahasiswa harus membuat program kerja bukan hanya sebagai formalitas tetapi yang mampu menjadikan pribadi yang lebih baik. ${ }^{25}$

Seperti hasil observasi, ${ }^{26}$ bahwasanya dulu di desa Cawang Lama terdapat anggota remaja Islam yang terdapat sekitar sepuluh orang anggota. Dulunya anggota remaja islam ini sangat aktif dalam berbagai kegiatan masjid dan melakukan ibadah sholat di masjid. Namun seiring dengan berjalannya waktu, satu persatu anggota remaja islam mulai sibuk dengan kegiatan dan aktifitas mereka masing-masing. Faktor lainnya remaja islam desa Cawang Lama tidak aktif lagi dikarenakan dengan beberapa faktor diantaranya yaitu faktor ketidak aktifan kepala desa yang seharusnya menjadi peran utama dalam maju dan berjalannya pemuda pemudi remaja islam. Kepala desa seharusnya memiliki ide seperti mencari guru pembimbing remaja islam agar remaja islam di desa Cawang Lama dapat bangkit dan berkembang dalam pembelajaran yang ada dalam organisasi remaja Islam. ${ }^{27}$ Kemudian faktor lainnya yaitu kurangnya minat para remaja yang disebabkan oleh pengaruh budaya asing seperti kecanggihan yang dirasakan. Saat ini para pemuda pemudi remaja islam banyak bermain game online dibandingkan dengan belajar dalam organisasi. Bahkan mereka enggan untuk sibuk dengan organisasi yang bersifat membangun karena bagi mereka hanya kesenangan sementara.

Salah satu faktor penyebabnya adalah dengan adanya perkembangan

${ }^{25}$ Wawancara dengan Silvia, Remaja Desa Cawang Lama, Tanggal 10 Juni 2020 pukul 10:00 WIB

${ }^{26}$ Wawancara dengan Silvia, Remaja Desa Cawang Lama, Tanggal 16 Mei 2020 pukul 13.43 WIB

${ }^{27}$ Wawancara dengan Satrio, Remaja Desa Cawang Lama, Tanggal 12 Juni 2020 pukul 14:00 WIB 
zaman yang memberikan pengaruh besar terhadap perubahan remaja serta teknologi yang semakin canggih dan meningkat. Tentu saja ini merupakan problem yang menjadi tanggung jawab bersama, baik bagi masyarakat maupun bagi mahasiswa kuliah kerja nyata sendiri. Oleh sebab itu, peran mahasiswa dalam kuliah kerja nyata ini sangat penting dalam meningkatkan nilai religius dalam diri remaja itu sendiri. Langkah awal yang dilakukan oleh mahasiswa yaitu melakukan wawancara mengenai latar belakang penyebab tidak aktifnya anggota remaja Islam serta alasan tidak berjalannya program dan kegiatan remaja islam. Inilah tugas mahasiswa selaku peserta kuliah kerja nyata dalam membangun dan mengembangkan keagamaan pada remaja. Ada pun yang dilakukan oleh mahasiswa peserta kuliah kerja nyata adalah dengan mengajak remaja berpartisipasi dalam program kerja yang telah dirancang oleh mahasiswa. Tentu saja melalui pendekatan awal, misalnya dengan melakukan perbincangan.

Jika membicarakan dampak tergantung dari cara bertugas mahasiswa KKN itu sendiri. Dapat dicontohkan seperti cara bergaul mereka dengan masyarakat, jika cara bergaul mereka kurang akrab dengan masyarakat tentu dampak negatiflah yang akan muncul seperti kurangnya rasa hormat bagi mereka di daerah tersebut. Namun jika cara mereka dalam berbaur dengan masyarakat itu baik, ramah, sopan tentu mereka akan dihormati sebagai mahasiswa terpelajar dimata masyarakat dan itulah yang menjadi nilai atau dampak positifnya. Tentunya dampak positif dan negatif itu muncul sesuai dengan pendekatan mahasiswa KKN kepada masyarakat, hal tersebut menjadi hal yang perlu diperhatikan oleh berbagai pihak yang berkaitan dengan kegiatan kuliah kerja nyata tersebut. ${ }^{28}$

Jadi dampak kuliah kerja nyata bagi masyarakat khususnya remaja adalah hal yang ditimbulkan dari proses pelaksanaan KKN tersebut. Hal ini bisa dijumpai seperti mengaktifkan kembali kegiatan anggota remaja islam desa Cawang Lama. Mahasiswa kuliah kerja nyata juga melakukan hal positif lainnya seperti mengajak sholat berjama'ah, membaca alquran di masjid sebelum sholat magrib. Dengan cara seperti inilah para mahasiswa kuliah kerja nyata dalam meningkatkan dan mengembangkan keagamaan pada remaja. Meskipun tidak maksimal, namun ini merupakan langkah awal yang

${ }^{28}$ Wawancara dengan Desva, Remaja Desa Cawang Lama, Tanggal 12 Juni 2020 pukul 13:40 WIB 
dilakukan mahasiswa kuliah kerja nyata.

\section{Kuliah Kerja Nyata dan Pengembangan Keagamaan Remaja}

Kuliah kerja nyata bertujuan untuk pembangunan dan pengembangan yang sifatnya berkelanjutan serta menjadikan masyarakat yang religius. Dalam hal ini, mahasiswa berperan sebagai motivator dalam proses pembangunan dan pengembangan keagamaan, baik pada masyarakat terutama remaja. Sehingga mahasiswa diharapkan mampu mengemas program yang sifatnya membangun sebaik mugkin.

Dalam pengabdiannya kepada masyarakat, mahasiswa diharapkan mampu menerapkan ilmu yang telah dipelajari dan menyalurkannya kepada masyarakat terutama pada remaja dan memberikan pengalaman pengetahuannya kepada remaja baik itu ilmu pengetahuan maupun ilmu keagamaan. Mahasiswa juga diharapkan mampu menjadi perantara dalam menyampaikan nilai-nilai pengetahuan maupun nilai-nilai keagamaan yang dibutuhkan oleh remaja.

Kuliah kerja nyata memberikan dampak pada pengembangan nilai keagamaan yang sudah cukup baik bagi anak-anak yang mereka ajarkan mengaji dalam program mereka selama mengemban tugas KKN. Membicarakan nilai keagamaan itu sama saja membicarakan tentang nilai spiritual quotient. Nilai ini merupakan nilai yang sangat utama karena berguna bukan untuk di dunia saja namun juga untuk akhirat juga. Oleh karena itu nilai ini bagi saya adalah yang paling penting untuk dijadikan program oleh para mahasiswa KKN ersebut. Jika untuk para remaja saya kira tidak begitu signifikan karena para remaja di suatu daerah kadang sudah sibuk dengan pekejaan masing-masing dan kurang aktif dalam bekerjasama dengan mahasiswa KKN sehingga kurangnya pengetahuan yang mereka dapatkan dari adanya program KKN yang dilaksanakan oleh para mahasiswa. ${ }^{29}$

Dalam pelaksanaannya, mahasiswa kuliah kerja nyata didorong untuk melaksanakan kegiatan di luar bidang studi. Hal ini dikarenakan mahasiswa perlu menelaah dan membantu memecahkan permasalahan yang sedang terjadi maupun yang sedang dihadapi oleh masyarakat khususnya pada remaja. Kegita kuliah kerja nyata tidak hanya melaksanakan program kerja, namun

${ }^{29}$ Wawancara dengan Ramadhani, Remaja Desa Cawang Lama, Tanggal 10 Juni 2020 pukul 13:27 WIB 
juga mampu memberikan pengaruh yang positif kepada masyarakat terutama pada remaja. Pengaruh merupakan efek yang ditimbulkan setelah dilakukannya sesuatu sehingga memberikan dampak kepada si penerima. Pengaruh yang terjadi bisa berupa perubahan sikap, perilaku, pengetahuan maupun pola pikir.

Jika pengembangan keagamaan bisa dilakukan mahasiswa KKN dengan baik terhadap remaja tentu manfaat yang remaja dapatkan itu sangat baik sekali. Contohnya dalam hal nilai-nilai spiritual para remaja yang biasanya kita ketahui bahwa banyak sekali para remaja kini sudah mengabaikan kewajiban mereka terhadap Allah SWT yaitu seperti sholat lima waktu. Oleh karena itu, jika para mahasiswa kkn mampu memberikan dorongan melalui berbagai program atau kegiatan seminar bagi remaja dalam hal mewujudkan remaja yang mempunyai nilai keagamaan yang baik serta mempengaruhi mereka dengan ilmu-ilmu yang diterapkan oleh mahasiswa tersebut, tentu secara otomatis saya katakan kuliah kerja nyata mereka sudah saya anggap berhasil karena kenapa? Karena, mereka mampu memberikan pengaruh yang baik dan signifikan bagi para remaja di daerah tempat mereka bertugas. ${ }^{30}$

Pengaruh yang ditimbulkan dalam kuliah kerja nyata pada remaja di desa Cawang Lama berupa perubahan perilaku. Dalam hal ini perubahan tersebut adalah remaja atau remaja Islam yang awalnya tidak aktif di masjid, jarang melaksanakan sholat berjama'ah di masjid, namun dengan adanya mahasiswa kuliah kerja nyata remaja islam desa Cawang Lama sudah mulai aktif mengisi masjid seperti sholat berjama'ah meskipun hanya sholat magrib dan belum maksimal. hal ini tentunya harus ada kerja sama antar mahasiswa kuliah kerja nyata, agar para remaja tidak surut dalam melaksanakan sholat berjama'ah. Mahasiswa peserta kuliah kerja nyata juga mengadakan semacam pengajian atau yasinan setiap malam Jumat baik di musholah maupun di masjid. Kegiatan tersebut dilakukan secara bergantian, sebab desa Cawang Lama memiliki dua tempat beribadah yaitu masjid dan musholah. Kegiatan ini pula di awali oleh mahasiswa peserta kuliah kerja nyata, kemudian dilakukan oleh remaja islam desa Cawang Lama, dan mahasiswa kuliah kerja nyata bertindak sebagai fasilitator. Namun terkadang dilakukan secara kombinasi

${ }^{30}$ Wawancara dengan Megi Hardiansyah, Remaja Desa Cawang Lama, Tanggal 12 Juni 2020 pukul 15:00 WIB 
yaitu dilakukan oleh mahasiswa dan remaja islam desa Cawang Lama. Dengan adanya mahasiswa kuliah kerja nyata di daerah tersebut, masjid yang kosong tadi bisa dimasuki oleh anak-anak ataupun remaja yang ada di daerah tersebut untuk belajar mengaji, mengadakan pengajian untuk semua kalangan, tadarus al-quran, ataupun mengadakan kegiatan keagamaan lainnya. ${ }^{31}$

Mahasiswa kuliah kerja nyata tidak hanya berada di lingkup remaja islam saja, namun juga berada di tengah-tengah anak-anak. Hal yang dilakukan oleh mahasiswa kuliah kerja nyata adalah ikut melakukan mengajar mengaji. Tentu ini merupakan batu loncatan bagi mahasiswa dalam membantu pemerintah dalam membangun dan mengembangkan nilai keagamaan pada anak-anak sebagai penerus bangsa yang religius. Selain mengajar mengaji pada anak-anak, mahasiswa peserta kuliah kerja nyata juga melakukan pemberian materi yang berkaitan dengan nilai-nilai keagamaan.

Mahasiswa kuliah kerja nyata $(\mathrm{KKN})$ juga menyampaikan materi kepada anak-anak Desa Cawang Lama yang dilakukan dengan menggunakan media, misalnya dengan media audio visual, dan white board yang bisa serta mudah dipahami oleh anak-anak dengan metode bercerita. Dalam hal ini anakanak dipersilahkan untuk mencatat materi yang disampaikan. Kegiatan ini dilakukan menurut jadwal setiap minggunya.Hal tersebut dilakukan dengan tujuan supaya anak-anak dapat mendapatkan wawasan dan ilmu yang lebih luas terkhusus di bidang keagamaan.

\section{Kesimpulan}

Simpulan hasil penelitian ini adalah yang pertama, dampak kuliah kerja nyata (KKN) bagi remaja Desa Cawang Lama, terlihat bahwa mahasiswa KKN dapat memberikan dampak positif atau negatif sesuai dengan beberapa hal yang dilakukan oleh para mahasiswa KKN tersebut. Mulai dari cara bergaul kepada masyarakat, program-program yang dilaksanakan, serta pengembangan keagamaan di Desa tersebut. Dampak positif yang ditimbulkan jika cara bergaul mereka baik kepada masyarakat, program kerja yang mendukung bagi pemberdayaan masyarakat, pengembangan keagamaan melalui kegiatan-kegiatan remaja masjid dan sejenisnya. Namun dampak negatif muncul jika kebalikan dari dampak positif tersebut yang terjadi. Kedua, dampak kuliah kerja nyata $(\mathrm{KKN})$ dalam pengembangan keagamaan

\footnotetext{
${ }^{31}$ Melya Nopita, Wawancara, 12 juni 2020
} 
bagi remaja dapat dilihat pada perubahan perilaku pada remaja tersebut, misalkan pada program yang diadakan oleh mahasiswa KKN seperti sholat berjamaah, mengajar mengaji Al-qur'an, yasinan setiap minggu, serta perayaan hari besar Islam. Dampak yang ditimbulkan ialah dampak positif dalam pengembangan keagamaan bagi masyarakat khususnya remaja yang semakin giat dalam beribadah dan mengikuti kegiatan keagamaan.

\section{Daftar Pustaka}

Amir, Fachrur Razi, and Syamsuddin Ali Nasution. "Pemberdayaan Masyarakat Melalui Kegiatan Pendidikan, Agama, Sosial, Ekonomi, Dan Kesehatan." Qardhul Hasan: Media Pengabdian Kepada Masyarakat 3.1 (2018)

Hidayat, Nur."Model Kuliah Kerja Nyata (KKN) Integratif Interkonektif Berbasis Pada Masyarakat Yang Produktif Inovatif Dan Kreatif." Panangkaran: Jurnal Penelitian Agama dan Masyarakat 2.2 (2019)

Lexy J.Moleong, Metodologi Penelitian Kualitatif Edisi Revisi, (Bandung: Remaja Rosdakarya, 2006)

Nurjanati, Dwi. "Pemasukan Materi Literasi Keuangan Dalam Kurikulum Program Kuliah Kerja Nyata (Kkn) Sebagai Media Edukasi Literasi Keuangan Pelaku UMKM." Prosiding Seminar Pendidikan Ekonomi dan Bisnis. Vol. 3. No. 1. 2017

Nurjanah, Nurjanah, and Ori Permata Lani."Opini Mahasiswa terhadap Pelaksanaan Kuliah Kerja Nyata (Kukerta) di Universitas Riau." Jurnal Online Mahasiswa Fakultas Ilmu Sosial dan Ilmu Politik Universitas Riau1.2 (2014).

Pemungkas, Alim Harun. Pengembangan Program Kuliah Kerja Nyata untuk Pemberdayaan Masyarakat Desa. (2016)

Saifuddin Azwar, Metode Penelitian, Yogyakarta, Pustaka Pelajar, 2012

Salehudin, Ahmad.” Pelaksanaan KKN Berparadigma Integrasi-Interkoneksi dalam Menopang Transformasi Masyarakat (Sebuah Rintisan Pendekatan Participatory Action Research).” Aplikasia: Jurnal Aplikasi Ilmu-ilmu Agama16.2 (2017)

Sudaryono, Metode Penelitian Pendidikan, Jakarta, Prenamedia Group, 2016 
236 | FOKUS : Jurnal Kajian Keislaman dan Kemasyarakatan Vol. 5, No. 2, 2020

Sugiyono, Memahami Penelitian Kualitatif, Bandung, Alfabeta, 2014

Sugiyono, Metode Penelitian Pendidikan, Bandung, Alfabeta, 2018

Suharsimi Arikunto, Prosedur Penelitian Suatu Pendekatan Praktek, Jakarta, Rineka Cipta, 2014

Widyasari, Widyasari, And Novi Maryani. Meningkatkan Peran Masyarakat Melalui Program Pendidikan Berbasis Tauhid Dalam Pembangunan Desa Yang Mandiri, Kreatif Dan Berbudaya. Qardhul Hasan: Media Pengabdian Kepada Masyarakat 3.1 (2018) 